\title{
$1 \quad$ Clopyralid degradation by AOPs enhanced with zero valent iron
}

2 M.B. Ferreira ${ }^{1,+}$, F.L. Souza ${ }^{2}$, M. Muñoz-Morales ${ }^{2,+}$, C. Sáez ${ }^{2}$, P. Cañizares ${ }^{2}$, C.A.

$4 \quad{ }^{1}$ Institute of Chemistry, Federal University of Rio Grande do Norte, Campus

$5 \quad$ Universitario 3000, 59078-970 Natal-RN, Brazil

$6{ }^{2}$ Department of Chemical Engineering, Faculty of Chemical Sciences and Technologies,

7 University of Castilla-La Mancha, Campus Universitario s/n. 13071 Ciudad Real, Spain

8 Abstract

9 Four different technologies have been compared (photolysis, ZVI+ photolysis, 10 electrolysis and ZVI + electrolysis) regarding the: (1) degradation of clopyralid, (2) extent of its mineralization, (3) formation of by-products and main reaction pathways. Results show that photolysis is the less efficient treatment and it only attains $5 \%$ removal of the pollutant, much less than ZVI, which reaches $45 \%$ removal and that electrolysis, which attains complete removal and $78 \%$ mineralization within $4 \mathrm{~h}$. When ZVI is used as pre-treatment of electrolysis, it was obtained the most efficient technology. The identification of transformation products was carried out for each treatment by LC-MS. In total, ten products were identified. Tentative pathways for preferential clopyralid degradation for all processes were proposed. This work draws attention of the synergisms caused by the coupling of techniques involving the treatment of chlorinated compound and sheds light on how the preferential mechanisms of each treatment evaluated occurred.

\section{Keywords}

Clopyralid degradation; ZVI; photolysis; electrolysis; coupled processes; reaction pathways 
- Oxidation capacity increases in the sequence: $\mathrm{UV}<\mathrm{ZVI}+\mathrm{UV}<\mathrm{EO}<\mathrm{ZVI}+\mathrm{EO}$.

- Higher rates of herbicides and mineralization were obtained in hybrid processes.

- High synergistic coefficients were obtained for the coupling of ZVI to UV and EO.

- Transformation products of clopyralid for each treatment have been identified

- Degradation pathways of clopyralid for each treatment evaluated were proposed.

32

33

34 *author to whom all correspondence should be addressed: manuel.rodrigo@uclm.es

35 +both authors contribute equally

36

37

38

39 


\section{Introduction}

42 In the recent years, it has emerged an increasing interest in the application of advanced oxidation processes (AOPs) to deplete chlorinated hydrocarbons that have been widespread in the environment, because of their use as pesticides, degreasing agents or solvents. Among the technologies evaluated, it is important to highlight the electrochemical advanced oxidation processes (EAOPs), which have experienced great

47 advances with the development of new electrodes materials, different processes and cells configurations, always searching for in order to increasing the cost-effectiveness of the treatments [1-4]. However, general drawbacks of these technologies are still those related to the high costs of electrode materials and the high power consumption required. To face these drawbacks, special design of cells looking for narrower electrode gaps and higher turbulences are looked for. Alternatively in some cases, it is proposed the addition of salts to the supporting electrolyte in order to increase the ionic conductivity, although this is not a sustainable choice because it leads to another type of pollution less hazardous but more persistent [5]. For these reasons, lots of studies have shown different alternatives to develop highly efficient electrochemical processes, based on the use of a

57 combination of technologies that can improve the treatments in terms of economy. The coupling of electro-oxidation with concentration technologies reduces the negative impact of the mass transfer limitations on the efficiency. Among the novel technologies, pollutants into flocs, reducing the volume of waste to be treated and making more

62 efficient the later electrolysis [6, 7]. It is also important the novel electrochemical cells that integrate the concentration of ionic organics by electrodialysis with their electrooxidation $[8,9]$. Finally regarding these novel concentration technologies, it has 
also been proposed an adsorption process with granular active carbon (GAC) that allows to concentrate the pollutants in methanol, from which they can be efficiently electrolyzed [10]. This later technology has also been successfully applied to remove gaseous pollutants, such as perchloroethylene [11].

Thereby, electrochemical technologies can be integrated in other processes that promote the indirect oxidation mechanisms, including UV light irradiation [12-14] or the applications of ultrasounds [15] to stimulate the formation of large amount of oxidants and free radicals, increasing the active substances that can react with the pollutants [1618]. Additionally, to increase the efficiency, other studies have considered the use of reductive pathways using carbonaceous cathodes to produce hydrogen peroxide [19]. These systems increase their efficiency by using pressurized systems or combining with catalysts (electro-Fenton (EF) processes) [20]. Besides, they have demonstrated to be successful even in the integral treatment of anaerobic sludge [21] and in the treatment of soil. With these novelties, it was developed a prototype for the efficient treatment of soil-washing wastes [22]. Considering other reductive pathways, many authors have studied the hydro-dechlorination, that appears as an efficient technology under mild reaction conditions (room temperature and atmospheric pressure). This nonelectrochemical process does not remove the pollutant but reduces its hazardousness and toxicity [23]. It requires expensive catalysts (including ZVI) and continuous bubbling of hydrogen. Because of that, in order to obtain a cheaper method and more easily integrated with other technologies, the use of zero valent iron (ZVI) in combination with electrolysis has emerged as a promising alternative. Successful results in the dechlorination were reported for short chain chlorinated paraffins [24], lindane [25] or trichloroethene [26], with studies included the evaluation of the intermediates generated and the possible degradation pathways. Regarding electrochemical processes, in previous 

works of our group about the combination of this technology with EAOPs, it was demonstrated that, from the viewpoint of electrochemical treatment, a pre-treatment with ZVI does not show important advantages regardless of the electrode material used and the size of the ZVI particles [27]. However, it was confirmed great improvements in biological treatability and toxicity of effluents after the application of these technologies [28]. In order to clarify the mechanism of the removal of chlorinated hydrocarbons, various authors have detailed reaction product formation using a photocatalytic degradation in $\mathrm{TiO}_{2}$ suspensions [29] and low pressure $\mathrm{UV} / \mathrm{H}_{2} \mathrm{O}_{2}$ treatment [30]. Recent studies report excellent results in the removal of persistent organic pollutants following the use of combined systems with the use of ZVI and electro-oxidation technology, as regards discharging standards, [31] biodegradability and toxicity [32] Furthermore, a system using a Fe foam (Fe-F) was used as catalyst in the presence of tripolyphosphate electrolyte (TPP) for electro-Fenton (EF) at neutral $\mathrm{pH}$, allowed an 8.55-fold increase in the rate of phenol degradation [33]. Nevertheless, to the best of our knowledge, there are no fundamental studies of the different degradation pathways which can result from the combination of ZVI dechlorination with AOPs technologies, such as photolysis or electro-oxidation

In this work, we compared the removal efficiency of a well-known herbicide, clopyralid (CLP), a polar organochlorinated compound effectively used to control annual and perennial broadleaf weeds, with two AOPs technologies, photolysis and diamond electrolysis, operated alone or coupled with a previous dehalogenation process with micro particles of ZVI. In this line, some of the most recent works related to the removal of CLP are summarized in Table 1 for the sake of comparison with the results that will be presented in this work. 


\begin{tabular}{|c|c|c|c|c|}
\hline Method & $\begin{array}{c}\text { Contaminant } \\
\text { Concentration }\end{array}$ & Experimental Conditions & Removal & Ref \\
\hline $\begin{array}{c}\text { ZVI and soil-washing } \\
\text { electrolysis }\end{array}$ & $30 \mathrm{mg} \mathrm{L}^{-1}$ & $\begin{array}{c}\mathrm{ZVI}=48 \mathrm{~g} \text { and } 72 \mathrm{~g} ; \mathrm{BDD} \text { anode and } \\
\text { stainless steel cathode; } \mathrm{T}: 40^{\circ} \mathrm{C} ; \mathrm{V}: 2 \mathrm{~L} \text {; } \\
\qquad \mathrm{J}=25 \mathrm{~mA} \mathrm{~cm}^{-2} .\end{array}$ & Complete. & [34] \\
\hline Electro-Fenton & $180 \mathrm{mg} \mathrm{L}^{-1}$ & $\begin{array}{l}\mathrm{Fe}^{2+}=0,1 ; 0,5 ; 1,2 \text { and } 5 \mathrm{mM} ; \text { Platinum } \\
\text { anode and carbon felt cathode; } \mathrm{T}= \\
20^{\circ} \mathrm{C} ; \mathrm{V}=0,8 \mathrm{~L}, \mathrm{~J}=50 ; 100,200 \text { and } \\
300 \mathrm{~mA} .\end{array}$ & $\begin{array}{l}80 \% \text { of } \\
\text { removal. }\end{array}$ & [35] \\
\hline $\begin{array}{c}\text { Low pressure } \\
\mathrm{UV} / \mathrm{H}_{2} \mathrm{O}_{2}\end{array}$ & $20 \mathrm{mg} \mathrm{L}^{-1}$ & $\begin{array}{c}\lambda=254 \mathrm{~nm} ;\left[\mathrm{H}_{2} \mathrm{O}_{2}\right]= \\
60 \mathrm{mg} \mathrm{L}{ }^{-1} ; \mathrm{V}=55 \mathrm{~mL} ; \text { Room } \\
\text { temperature.. }\end{array}$ & $\begin{array}{l}56 \% \text { of } \\
\text { removal. }\end{array}$ & [36] \\
\hline $\begin{array}{c}\mathrm{UV} / \mathrm{H}_{2} \mathrm{O}_{2} \text { and ozone } \\
\text { oxidation }\end{array}$ & $\begin{array}{c}0.078,0.260, \\
0.391 \text { and } 0.521 \\
\mathrm{mmol} \mathrm{L}^{-1}\end{array}$ & $\begin{array}{c}{\left[\mathrm{H}_{2} \mathrm{O}_{2}\right]=1 \mathrm{~g} \mathrm{~L}^{-1} \text { and } 2 \mathrm{~g} \mathrm{~L}^{-1} \mathrm{~V}=200} \\
\mathrm{~mL} ; \mathrm{T}=\text { at } 25 \pm 2{ }^{\circ} \mathrm{C}\end{array}$ & $\begin{array}{l}\text { Complete } \\
\text { removal with } \\
{\mathrm{UV} / \mathrm{TiO}_{2}} \text {. }\end{array}$ & [37] \\
\hline $\begin{array}{l}\text { Photoelectrochemical } \\
\text { oxidation and } \\
\text { Sonoelectrochemical } \\
\text { oxidation }\end{array}$ & $0.02 \mathrm{mg} \mathrm{g}^{-1}$ & $\begin{array}{l}\text { BDD anode and stainless steel cathode; } \\
\text { ultrasound source of low ( } 200 \mathrm{~W}) \text { and } \\
\text { high frequency }(450 \mathrm{~W}) \text {; uv lamp ( } 254 \\
\mathrm{~nm}) ; \mathrm{T}=25^{\circ} \mathrm{C} ; \mathrm{J}=12.8 \mathrm{~mA} \mathrm{~cm}^{-2} \text {. }\end{array}$ & Complete. & [12] \\
\hline $\begin{array}{c}\text { Electrochemical } \\
\text { oxidation with GAC } \\
\text { adsorption }\end{array}$ & $120 \mathrm{mg} \mathrm{L}^{-1}$ & $\begin{array}{l}\text { BDD anode and stainless steel cathode; } \\
\mathrm{V}=1 \mathrm{~L} ; \mathrm{T}=25 \pm 1^{\circ} \mathrm{C} ; \mathrm{J}=20-30 \mathrm{~mA} \\
\qquad \mathrm{~cm}^{-2}\end{array}$ & Complete. & [38] \\
\hline $\begin{array}{l}\text { ZVI, electrolysis and } \\
\text { photolysis }\end{array}$ & $30 \mathrm{mg} \mathrm{L}^{-1}$ & $\begin{array}{c}{[\mathrm{ZVI}]=45 \mathrm{~g} \mathrm{~L}^{-1} ; \mathrm{BDD} \text { and DSA anode; }} \\
\text { UV lamp }(11 \mathrm{~W}) ; \mathrm{V}=1 \mathrm{~L} ; \text { Room } \\
\text { temperature; } \mathrm{J}=50 \mathrm{~mA} \mathrm{~cm}{ }^{-2}\end{array}$ & $\begin{array}{l}\text { Complete with } \\
\text { BDD anode. }\end{array}$ & [28] \\
\hline $\begin{array}{l}\text { Electrodialysis and } \\
\text { electro-oxidation }\end{array}$ & $100 \mathrm{mg} \mathrm{dm}^{-3}$ & $\begin{array}{c}\mathrm{BDD} \text { and } \mathrm{MMO} \text { anodes; } \mathrm{NaCl} \text { and } \\
\mathrm{Na}_{2} \mathrm{SO}_{4} \text { as supporting electrolytes; } \mathrm{J}= \\
177.7 \mathrm{~A} \mathrm{~m}^{-2} ; \mathrm{V}=1 \mathrm{dm}^{3} \text {. }\end{array}$ & $\begin{array}{l}\text { Higher removal } \\
\text { rates for the } \\
\text { BDD anode. }\end{array}$ & [39] \\
\hline Photoelectrolysis & $100 \mathrm{mg} \mathrm{dm}^{-3}$ & $\begin{array}{l}\text { Novel laser-prepared mixed metal oxide } \\
\left(\mathrm{MMO} \mathrm{RuO}_{2} \mathrm{TiO}_{2}\right) \mathrm{NaCl}\left(3.7 \mathrm{~g} \mathrm{~L}^{-1}\right) \text { and } \\
\quad \mathrm{Na}_{2} \mathrm{SO}_{4}\left(3 \mathrm{~g} \mathrm{~L}^{-1}\right) \text { as supporting } \\
\text { electrolytes } \mathrm{j}=30 \mathrm{~A} \mathrm{~m}^{-2} ; \mathrm{V}=150 \mathrm{~mL} \text {. }\end{array}$ & $\begin{array}{l}\text { Non total } \\
\text { removal. MMO } \\
\text { more effective } \\
\text { in } \mathrm{NaCl} \text { media }\end{array}$ & [40] \\
\hline
\end{tabular}

116 In this case, it has also evaluated the kinetics of the combined process, mineralization decay, identification of transformation products to conclude with the discussion of tentative degradation pathways proposed for each technology studied, in order to shed light on the treatability of such wastes, which allows a more efficient design of future applications. 
123 Chemical reagents. All chemicals were purchased of reagent grade and used as received. Clopyralid $-\mathrm{C}_{6} \mathrm{H}_{3} \mathrm{Cl}_{2} \mathrm{NO}_{2}, 99 \%$ purity, solubility $>1 \mathrm{~g} \mathrm{~L}^{-1}$ at $20^{\circ} \mathrm{C}, \mathrm{K}_{\mathrm{ow}}=$ $2.34^{-3}$ at $\mathrm{pH} 7$ and $20^{\circ} \mathrm{C}$ (a.r., Sigma-Aldrich) was selected as a model of organic compound. Iron zero valent, $\geq 99 \%$, granular, $10-40$ mesh, average size is $568 \mu \mathrm{m}$. Methanol HPLC grade and formic acid were used as mobile phase. Sodium sulphate anhydrous used as supporting electrolyte. These chemicals were purchased from SigmaAldrich, Spain). Sulfuric acid (98\%), sodium hydroxide pellets $(97 \%)$ were obtained (a.r., Scharlab, Spain) and used to control pH. Double deionized water (Millipore MilliQ system, resistivity: $18.2 \mathrm{M} \Omega \mathrm{cm}$ at $25^{\circ} \mathrm{C}$ ) was used to prepare all solutions.

Experimental set-up. In order to evaluate the efficiency of the combined technologies, four strategies were developed. The first one consists of applying single electrochemical treatment employing a single flow cell (SFC) using boron-doped diamond electrodes with $78 \mathrm{~cm}^{2}$ of area as anode and cathode (WaterDiam, France). A $1.5 \mathrm{~L}$ glass reactor was filled with $1 \mathrm{~L}$ of water containing $30 \mathrm{mg} \mathrm{L}^{-1}$ of clopyralid and $7.04 \mathrm{mM}$ of $\mathrm{Na}_{2} \mathrm{SO}_{4}$. The electro-oxidation was carried out galvanostatically by applying a current density of $50 \mathrm{~mA} \mathrm{~cm}^{-2}$ as it was explained elsewhere [27]. The second strategy consists of a photochemical treatment using the same set up described early coupled to UV lamp of $11 \mathrm{~W}$ and wavelength of $254 \mathrm{~nm}$. UV lamp is a cylinder tube of $15 \mathrm{~cm}$ of length and $10 \mathrm{~mm}$ of diameter and it was $80 \%$ covered by water in a vertical position. UV light was irradiated directly to the tank without applying any electrical current. The combined strategies consist of the pre-treatment of the waste for $72 \mathrm{~h}$ with $45 \mathrm{~g} \mathrm{~L}^{-1}$ of ZVI (stirring rate $300 \mathrm{rpm}$ ) followed by application of photolysis or electrolysis process as described above. Optimum experimental conditions for ZVI dehalogenation were determined in preliminary experiments as described elsewhere [34]. Before the application of AOPs processes, clopyralid solutions were filtered with $0.45 \mu \mathrm{m}$ Nylon Supelco filters to 
avoid the possible iron suspended particles generated in the dehalogenation process. All experiments were conducted for 240 minutes and samples were taken at defined times along the experiments. Temperature of the system was kept constant $\left(25^{\circ} \mathrm{C}\right)$ by means of a thermostatic bath (JP Selecta, Digiterm 100) and a heat exchanger. The monitored parameters were $\mathrm{pH}$ and conductivity of the solution, total organic carbon (TOC), clopyralid concentration and intermediates generated.

\section{Analytical techniques}

Selected samples were collected and filtered with $0.22 \mu \mathrm{m}$ Nylon Supelco filters before analysis. The quantification of the clopyralid and some dehalogenated intermediates were carried out by HPLC (Agilent 1200 series) using a ZORBAX Eclipse Plus5 C18 analytical column. The mobile phase consisted of $30 \%$ methanol / $70 \%$ water with $0.1 \%$ of formic acid (flow rate: $0.8 \mathrm{~mL} \mathrm{~min}^{-1}$ ). The DAD detection wavelength was $280 \mathrm{~nm}$, the retention time around $2.6 \mathrm{~min}$, the temperature was maintained $25^{\circ} \mathrm{C}$ and the injection volume was $20 \mu \mathrm{L}$. The TOC concentration was monitored using a Multi N/C 3100 Analytic Jena Analyser. The evolution of the $\mathrm{pH}$ and conductivity were determined by a $\mathrm{pH}$ meter Crison $\mathrm{pH} 25+$ and a conductometer Crison CM35+ (Crison Instruments, Spain), respectively. Both instruments were calibrated regularly with standard solutions and all the samples were measured in duplicate. The reactions intermediates of clopyralid were identified by Liquid Chromatography-Mass Selective Detector (LC-MSD) using a Zorbax SB-C18 $(150 \mathrm{~mm} \times 4.6 \mathrm{~mm}, 3.5 \mu \mathrm{m}$ particle size) column (Agilent Technologies CA, USA). Detection was carried out with a UV-Vis diode array detector (DAD) at 230 and $280 \mathrm{~nm}$ (Agilent, 1260 infinity model) equipped with a flow cell coupled in series to an Agilent 6110 series MS detector (Waldbronn, Germany) equipped with an atmospheric pressure ionization source electrospray (API-ES). Selected samples were analyzed using the ESI interface in positive ionization (PI) mode. For the analysis in PI 
mode a gradient elution was performed by a binary gradient, composed of solvent $\mathrm{A}$ (water/0.1\% $\mathrm{HCOOH}$ ) and solvent $\mathrm{B}$ (acetonitrile/0.1\% $\mathrm{HCOOH}$ ) according to the following program: initial conditions $80 \% \mathrm{~A}$, kept constant for $1 \mathrm{~min}$, decreased to $50 \%$ in $4 \mathrm{~min}$, decreased to $20 \%$ in $6 \mathrm{~min}$, kept constant for $8 \mathrm{~min}$, returned to the initial conditions after 2 min. Re-equilibration time was set at $2 \mathrm{~min}$, while the total run analysis lasted 10 min. Column temperature was set at $25^{\circ} \mathrm{C}$, injection volume and flow rate were $1000 \mu \mathrm{L}$ and $1 \mathrm{~mL} \min ^{-1}$, respectively. To optimize the MS detection of each analyte, the drying gas flow was investigated within the $1.0-13.0 \mathrm{~L} \mathrm{~min}^{-1}$. The temperature of the drying gas was also studied in a range from 50 to $350^{\circ} \mathrm{C}$. The capillary voltage ranged from 2000 to $6000 \mathrm{~V}$. Additionally, the nebulizer pressure, ranged from 5.0 to $60 \mathrm{psi}$, and the fragmentor from 50 to 200 .

\section{Results and discussion}

Fig. 1 shows the evolution of clopyralid and TOC as a function of time in the four treatment technologies evaluated in this work. Regarding herbicides decay (Fig. 1a), the photolytic process exhibited very low removal attaining only $10 \%$. Although the pesticide absorbs UV light, the efficiency of this kind of treatment depends on many factors like UV fluence, irradiation time, molecule structure, etc. In the case of clopyralid structure, as discussed by Wilzbach and Rausch, 1970 [41], even though there is a presence of a heteroatom and an aromatic system in its structure, the photochemical dissociation mechanism of the pyridine ring is through of the $\mathrm{n} / \mathrm{p}^{*}$ excitation, leading to a bicyclic valence isomer, Dewar pyridine, which re-aromatizes completely to pyridine in a few minutes at room temperature. This important phenomena was also discussed by Semitsoglou-Tsiapou et al, that showed that clopyralid (55 $\mathrm{mL}$ containing $20 \mathrm{mg} \mathrm{L}^{-1}$ ) was hardly susceptible to low-pressure 
photolysis, achieving only $1.2 \%$ of removal, although it follows the same mechanism [36].

Similarly, the treatment with ZVI particles for $72 \mathrm{~h}$ led to a slight decrease in the clopyralid removal (around $5 \%$ ). To understand this value, it is important to consider that the pesticide concentration in this work is higher than that used in others works in the literature. Thus, Correia et al 2013 [42], studied the 2,4-D degradation by ZVI and showed around $50 \%$ degradation was achieved in the presence $2 \%$ w/v of ZVI after 150 min. However, when photolysis was applied after the ZVI process, the degradation of pesticide was accelerated, increasing the rate of removal from 5\% to 58\%. This behavior can be explained in terms of the presence of oxygen (mixing kept for $72 \mathrm{~h}$ ) during the ZVI treatment, which allows to transform the ZVI reducing conditions into oxidative reactions. Thus, oxygen reacts with ZVI generating $\mathrm{O}_{2}{ }^{2-}$, which can react further through two routes. The reduction of $\mathrm{O}_{2}$ through a $4 \mathrm{e}^{-}$pathway with production of $\mathrm{H}_{2} \mathrm{O}_{2}$ as an intermediate and a $2 \mathrm{e}^{-}$pathway, with formation of $\mathrm{H}_{2} \mathrm{O}_{2}$ as product. From this point of view, the efficiency of oxidative degradation of clopyralid depends on the extent to which the branching process favors hydroxyl radical formation by reduction of $\mathrm{H}_{2} \mathrm{O}_{2}$ through 2e-pathway[42]. Thus, the photo-assistance in the UV promotes the Fenton reaction, yielding ${ }^{\bullet} \mathrm{OH}$. Furthermore, studies previous $[43,44]$ suggest that the photo radiation in the presence of $\mathrm{ZVI}$ can promote $\mathrm{ZVI} / \mathrm{O}_{2}$ reaction to produce $\mathrm{HO} \cdot$ as shown following Eqs. (1) and (2), enhancing the process efficiency

$\mathrm{Fe}^{0}+\mathrm{O}_{2}+2 \mathrm{H}+\rightarrow \mathrm{Fe}(\mathrm{II})+\mathrm{H}_{2} \mathrm{O}_{2}$

On the other hand, results demonstrate that the single EO process is a suitable 
after $180 \mathrm{~min}$ of treatment (current charge of $1.6 \mathrm{Ah} \mathrm{dm}^{-3}$ ). Considering the cell voltage, this means that the energy consumed in the process was only $11.46 \mathrm{kWh} \mathrm{m}^{-3}$. These results are expected considering the formation of hydroxyl radical on the surface of the anode, which will be discussed later. In addition, other oxidants are expected to be formed with this technology and as reported in the literature, when sulfate radicals are present in the medium, they can be transformed into persulfate [45-47]. These electrogenerated oxidant species may produce mediated oxidation in the bulk solution, complementing the mechanisms of oxidation and contributing to an increase in global oxidation efficiency. In order to expedite the electro-oxidation, previous treatment with ZVI particles was added to this technique. The addition led to slight improvement of the process performance, decreasing the time to attain the complete herbicide removal.

Fig. $1 \mathrm{~b}$ shows the performance of the treatment techniques regarding to the mineralization of the solution. As can be seen, the single ZVI treatment does not provide significant mineralization (only 5\%). Photolysis, as well, yields only $10 \%$ mineralization after $180 \mathrm{~min}$. Despite ZVI + photolysis improved the degradation of CLP, the mineralization only reached $22 \%$. This behavior can be attributed to the dechlorination of the CLP, which makes the structure more vulnerable to photolysis. On the other hand, despite $\mathrm{EO}$ and $\mathrm{ZVI}+\mathrm{EO}$ were able to attain complete CLP degradation, around $20 \%$ of initial TOC still remained in the solution. This means that organic content corresponds to the degradation by-products of CLP. However, the ZVI + EO process was found to give a remarkable improvement in the mineralization, increasing the efficiency from 4.3 to $4.9 \mathrm{mg}$ TOC (Ah) ${ }^{-1}$. 

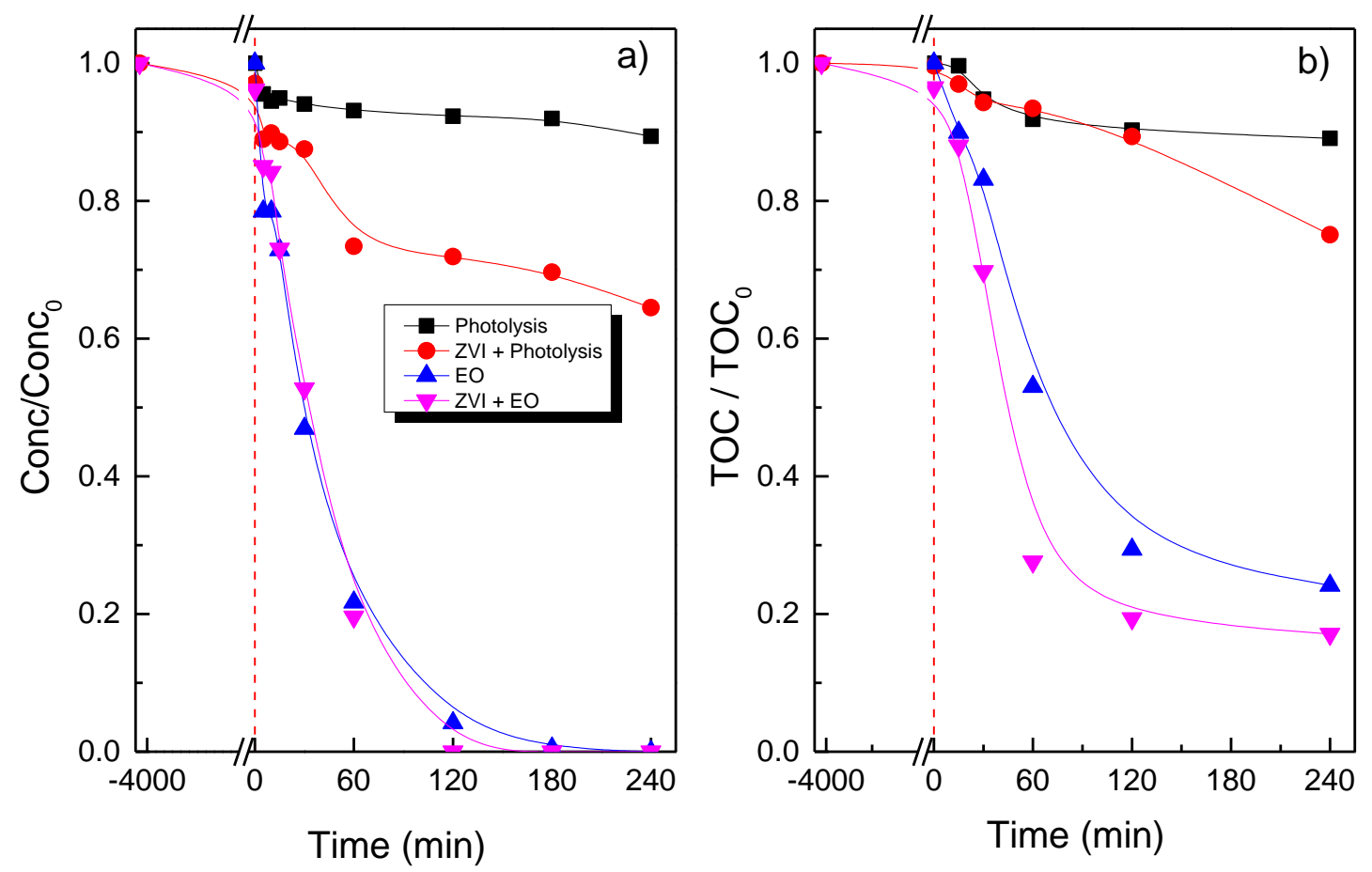

Figure 1. Relative removal of Clopyralid and b) Relative TOC decay as a function of time during the (घ) photolysis; $(\bullet) \mathrm{ZVI}+$ photolysis, $(\boldsymbol{\Delta}) \mathrm{EO}$ and ( $\boldsymbol{\nabla}) \mathrm{ZVI}+\mathrm{EO}$.

Concentration and TOC decay were fitted to a pseude first-order kinetics, and values are reported in the Fig. 2a. As expected, values obtained for ZVI process were very low (in the range of $10^{-7} \mathrm{~min}^{-1}$ ) for both CLP and TOC removal. Photolytic process also presents low reaction rate $\left(10^{-4} \mathrm{~min}^{-1}\right)$, albeit higher as compared to ZVI process. When light is applied, a significant improvement is observed $\left(10^{-4}\right.$ to $\left.10^{-2} \mathrm{~min}^{-1}\right)$, explained in terms of an increase in hydroxyl radical production stemming from the photolysis of $\mathrm{H}_{2} \mathrm{O}_{2}$, which accelerates the oxidation rate of all organic compounds present in the medium and contributes to the optimization of the process performance. Besides, ZVI + EO process shows a higher increasing of the amount of hydroxyl radicals and other oxidants formed on the BDD surface and in the bulk (such as persulfates, ozone and peroxide species). On the other hand, analyzing the mentioned combined process ZVI+ 
$\mathrm{EQ}$, it is possible to see that $\mathrm{k}$ values for CLP oxidation and mineralization did not

increase with the pre-treatment with ZVI. Nevertheless, a significant improvement is observed in the mineralization when electrooxidation using diamond electrodes is assessed in comparison with photolytic processes. This behavior suggests a constant electrolytic production of ${ }^{\bullet} \mathrm{OH}$ radicals from reaction (3), which acts mainly in the oxidation of byproducts in the bulk.

$$
\mathrm{H}_{2} \mathrm{O} \rightarrow{ }^{\bullet} \mathrm{OH}+\mathrm{H}^{+}+\mathrm{e}^{-}
$$

In order to evaluate quantitatively the synergistic effect when two or more process are combined, the synergistic index was calculated from kinetics values according to eq. 4.

$$
\text { Sinergistic index }(S)=\frac{k_{Z V I+P H O T O}}{K_{Z V I}+k_{\text {PHOTO }}}
$$

Figure $2 b$ shows the synergistic index of the combined system obtained for 2,4-D CLP and TOC removal. The first combined process (ZVI + photolysis) is called S1 while the combination ZVI+ EO is called S2. Synergy index values $>1$ indicate that there is a synergism effect when process is combined. Considering the clopyralid removal, the values obtained from Eq. (4) yields a synergistic index of 5.1 for S1 and 10.1 for S2, indicating a strong synergistic effect for 2,4-D CLP removal and both hybrid process. However, S values equal to 0.93 and 1.2 were obtained for S1 and S2 for TOC decay indicating an almost nil synergistic effect for mineralization. These results indicate that ZVI is acting in the transformation of CLP via reductive dechlorination reactions. In this way their concentration decreases significantly. However, after successive elimination of $\mathrm{Cl}$ atoms, the $\mathrm{ZVI}$ is not able to degrade the more recalcitrant molecule formed to $\mathrm{CO}_{2}$ and water and neither the EO process is able to get a total removal. Then, results indicate that the application of combined process ZVI + EO is not an excellent mechanism for the mineralization of organic compound once the target 

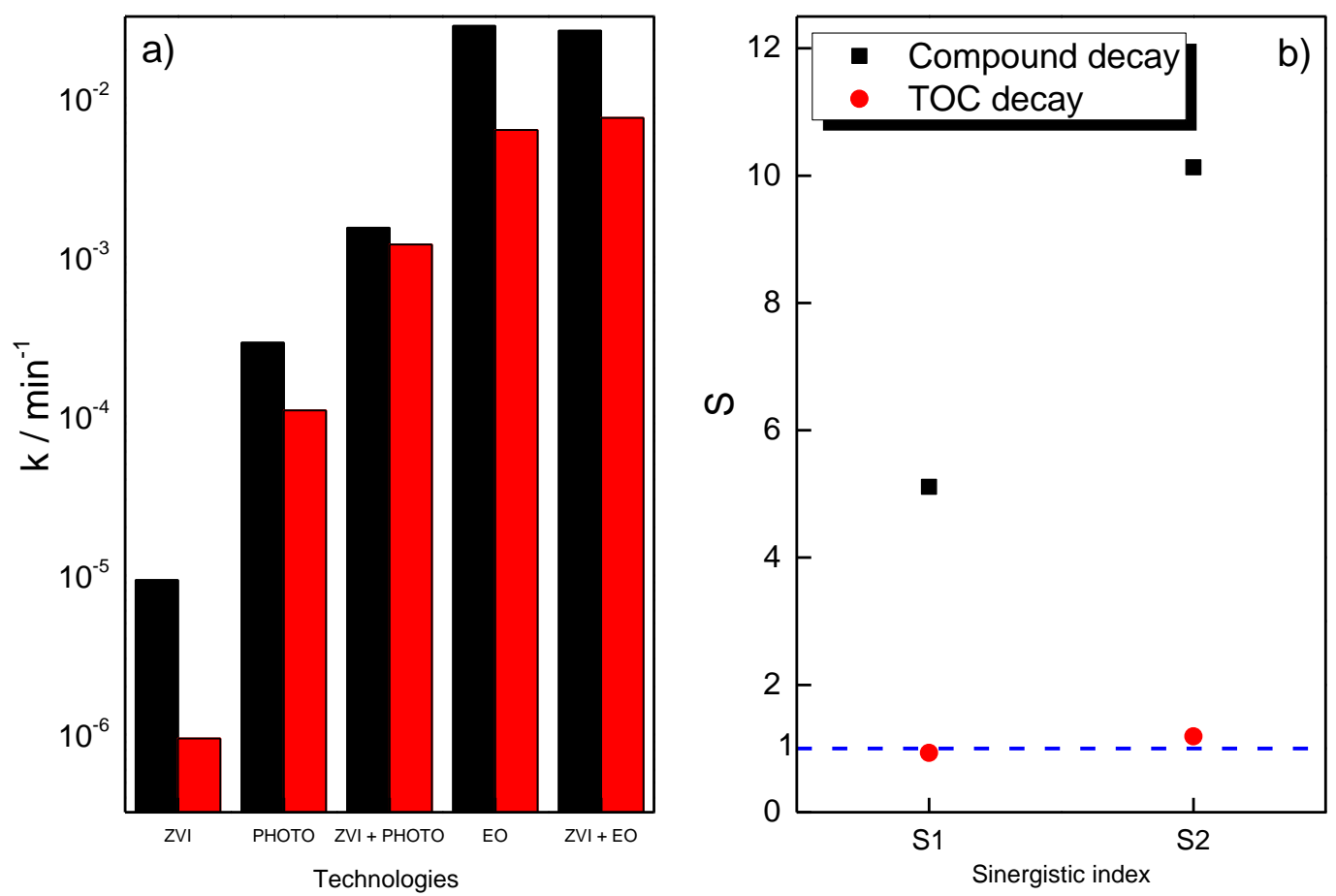

Figure 2. a) Kinect constants obtained after fitting the clopyralid and TOC decay results to a first-order kinetic reaction model. b) Synergistic effect calculated for ( $\mathbf{\square})$ compound decay and $(\bullet)$ TOC

In Fig. 3, it can be seen the evolution of $\mathrm{pH}$ and conductivity during the treatments evaluated. These parameters give an information about the species generated during the treatments. As seen, after $72 \mathrm{~h}$ of the ZVI pre-treatment, there is a slight decrease in the solution $\mathrm{pH}$. However, this parameter remained unchanged during the coupled processes (e.g ZVI + photolysis and ZVI+EO). In addition, it was not observed the formation of iron hydroxides and just low concentration of iron (II) ions and chloride were obtained according with eq (5) because of the low hydroxyl ions released during 
the whole pre-treatment proposed. However, further research should be necessary to

299

300

301

302

303

304

305

306

307

308

309

310

311

know more about these iron products.

$$
\mathrm{Fe}^{0}+2 \mathrm{H}_{2} \mathrm{O} \rightarrow \mathrm{Fe}^{2+}+\mathrm{H}_{2}+2 \mathrm{OH}^{-}
$$

Then, this indicates that reduction reactions can promote the generation of mildly acid species. During the photolytic process, the $\mathrm{pH}$ remained stable. This behavior was expected since considerable changes were observed in the treatment process (as observed in the Fig.1ab). The remarkable change in the $\mathrm{pH}$ was observed after the electro-oxidation process, for which there is an increase of $\mathrm{pH}$ from 5.2 to 9.5. In terms of conductivity, their changes were negligible over the whole reaction period in the photolysis and ZVI + photolysis processes. However, the values significantly increased during the electro-oxidation processes. This can be explained not only by the changes in the $\mathrm{pH}$ but also in terms of the larger generation of oxidant species, initially produced through a low concentration of $\mathrm{H}_{2} \mathrm{O}_{2}$ generated prior to the efficient radicals promoted by EO processes as it was suggested by Minella et al.[48] at slightly acid pH. 

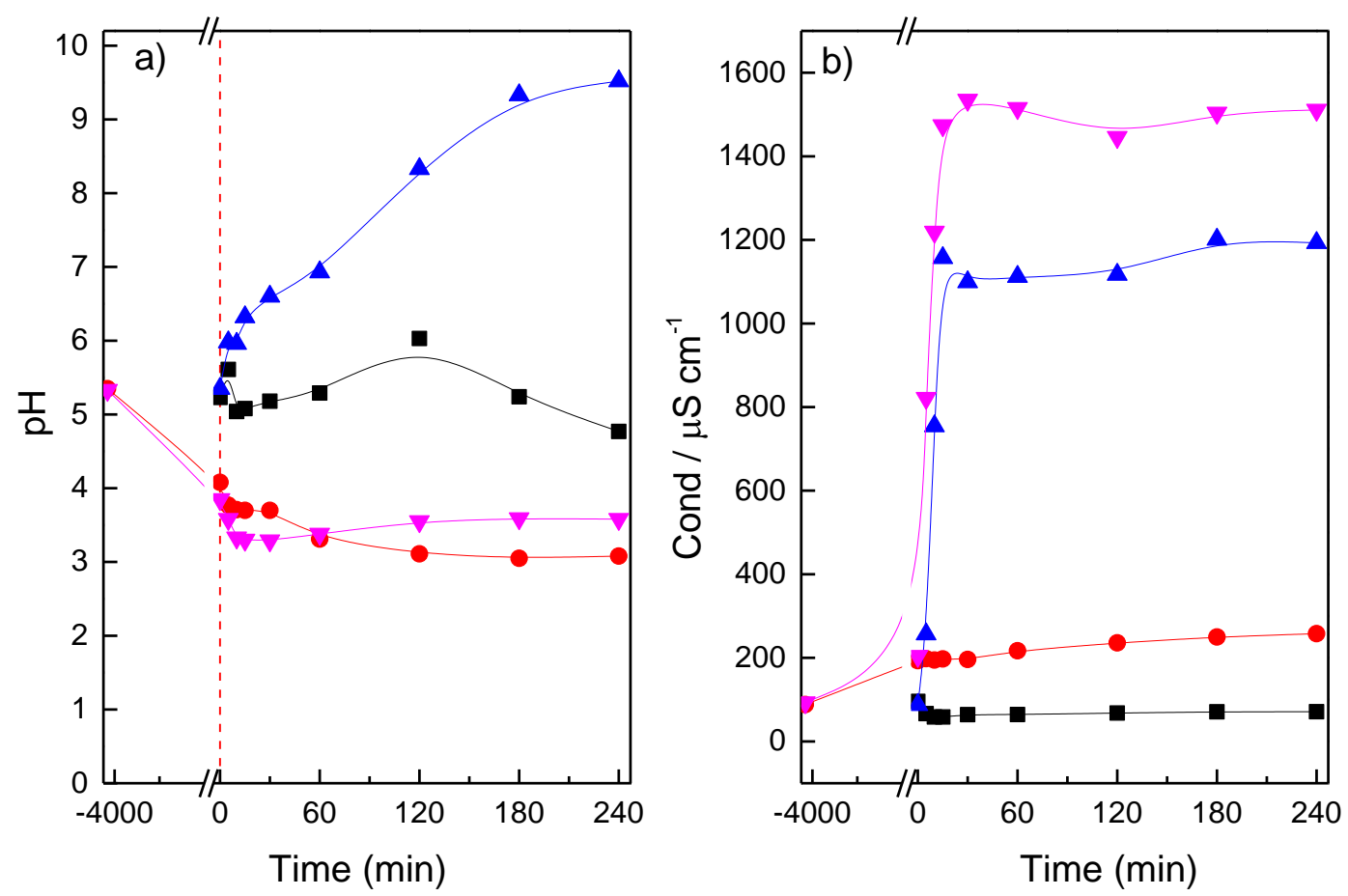

Figure 3. a) $\mathrm{pH}$ and b) Conductivity evolution as a function of time during the ( $\mathbf{a})$ photolysis, ( $\mathrm{ZVI}+$ photolysis, $(\boldsymbol{\Delta}) \mathrm{EO}$ and ( $\boldsymbol{\nabla}) \mathrm{ZVI}+\mathrm{EO}$.

Fig. 4 shows the HPLC chromatograms of the processed samples in the four evaluated processes. It can be observed the higher peak is related to Clopyralid at retention time 2.8 min. Besides, a very short number of byproducts appear in chromatograms. This may be a reflection of the low concentration of the byproducts generated. It is possible to see two important reaction products in retention times at 1.0 and $1.4 \mathrm{~min}$. Both peaks appear during the photolytic process, being the most relevant at $1.4 \mathrm{~min}$. However, in the ZVI + photolysis (fig.4b) this peak is lower than in photolysis and quickly disappears. Fig, c shows that during the EO technology, CLP was destroyed within few minutes of reaction. The byproduct at $1.4 \mathrm{~min}$ was not found and the peak at $1.0 \mathrm{~min}$ is negligible. In the presence of ZVI particles as pre-treatment of the EO process, it can be 

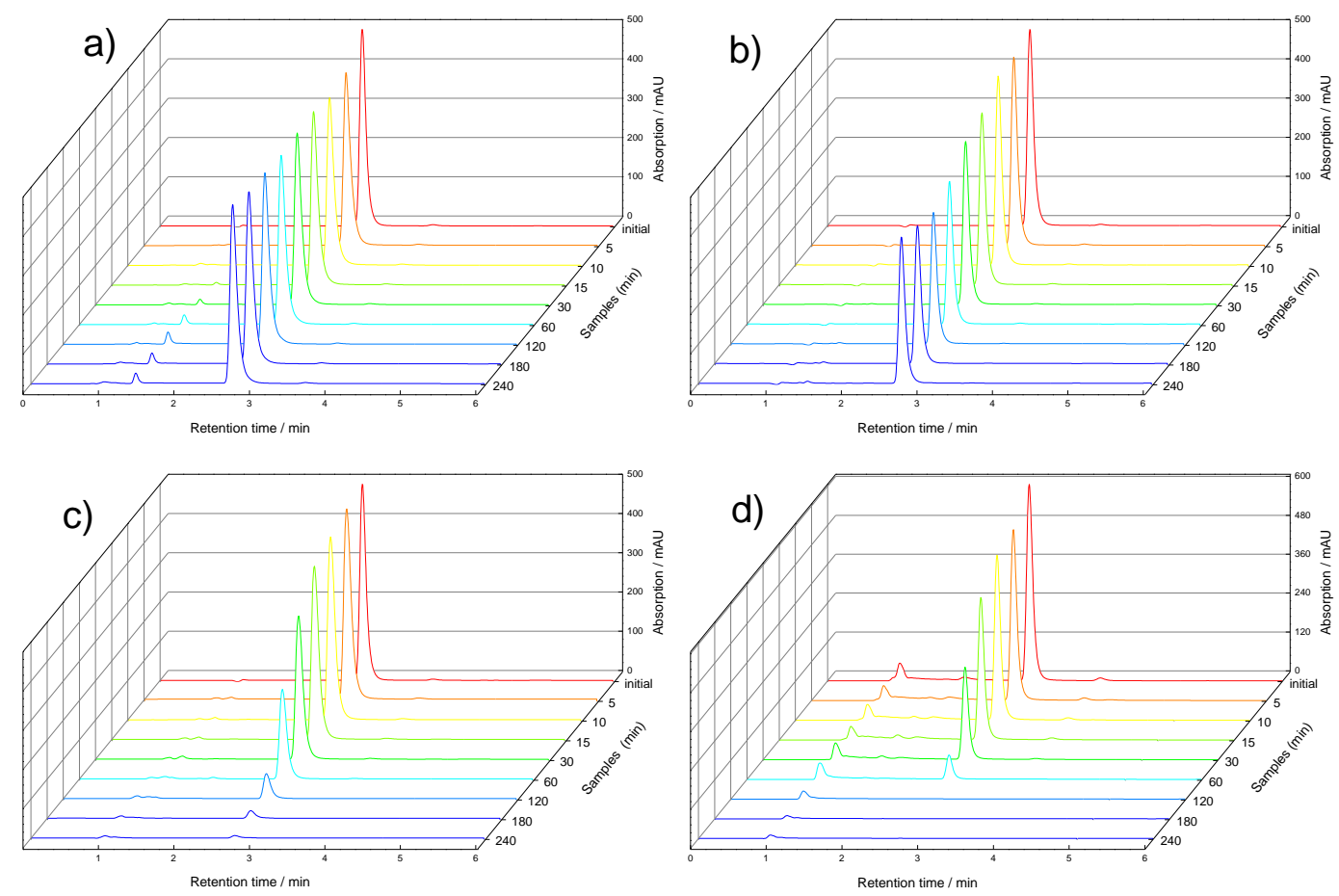

Figure 4. Chromatograms obtained from HPLC analysis for each sample taking during

a) photolysis process; b) ZVI + photolysis; c) EO process and d) ZVI + EO. (Eluent: water with $0.1 \%$ formic acid and acetonitrile $30: 70 \mathrm{v} / \mathrm{v}$; flow rate: $1 \mathrm{~cm}^{3} \mathrm{~min}^{-1}$, Vol. inj.: $20 \mu \mathrm{L}$; Column: Zorbax Eclipse Plus $5 \mathrm{C} 18,30 \mathrm{~cm} ; \lambda=280 \mathrm{~nm}$; Temp. $25^{\circ} \mathrm{C}$ )

These two important by-products were identified based on the literature and throughout of internal standard method. Peaks were quantified with external standard calibration based on areas from the standard reagents. The by-product at 1.0 min was identified as pyridine- 2-carboxylic acid and the product at $1.4 \mathrm{~min}$ as 6-chloro-3-hydroxypyridine-2carboxylic acid. As it can be seen in the Fig.5ab, both concentrations are very low. One 
important point to be considered is the fact that the both products mainly appears after using the ZVI as pre-treatment. The pyridine-2-carboxilic acid concentration (Fig.5a) decreases with time when UV irradiation is coupled to ZVI process. Besides, it is completely oxidized within 50 minutes of electro-oxidation (ZVI+EO). Regarding to 6chloro-3-hydroxypyridine-2-carboxylic acid (Fig.5b), its concentration remains unchanged over time when ZVI + photolysis process was accomplished. This behavior means that this product is more refractory, and it does not undergo photolytic cleavage easily. However, it is completely degraded with ZVI+EO process.
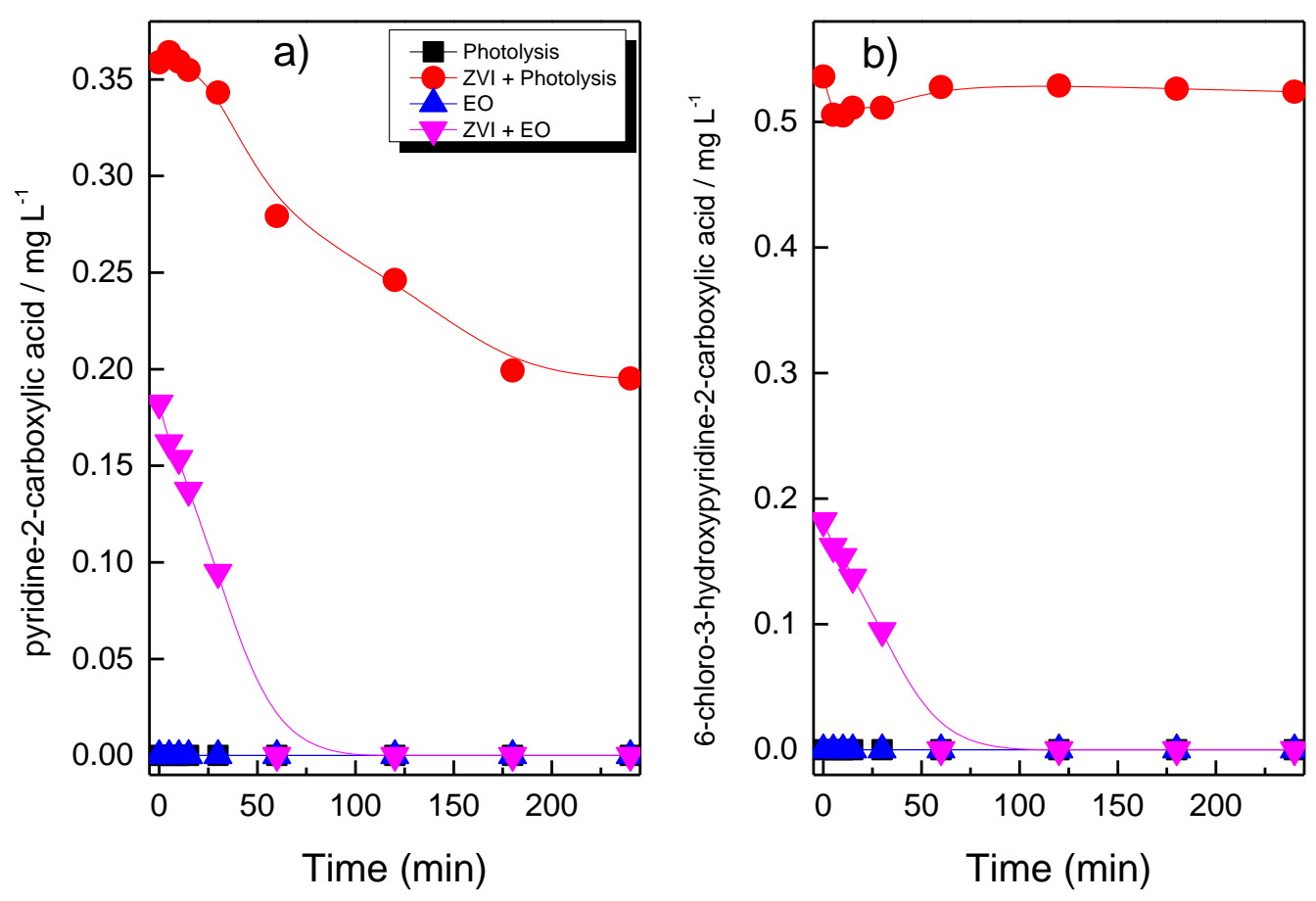

Figure 5. Intermediates evolution as a function of time during the ( $\mathbf{a})$ photolysis;

ZVI + photolysis, ( $\mathbf{\Delta})$ EO and ( $)$ ZVI + EO. a) pyridine-2-carboxylic acid and b) 6chloropyridine-2-carboxylic acid. 
shown in eqs. 6 and 7 or by cathodic hydro-dehalogenation reactions, which should lead to the formation of the same intermediates but without production of iron (II) ions (eqs. 8 and 9) [34]

$$
\begin{gathered}
\mathrm{Fe}^{0}+\mathrm{C}_{6} \mathrm{H}_{3} \mathrm{Cl}_{2} \mathrm{NO}_{2}+\mathrm{H}^{+} \rightarrow \mathrm{Fe}^{2+}+\mathrm{C}_{6} \mathrm{H}_{4} \mathrm{ClNO}_{2}+\mathrm{Cl}^{-} \\
\mathrm{Fe}^{0}+\mathrm{C}_{6} \mathrm{H}_{4} \mathrm{ClNO}_{2}+\mathrm{H}^{+} \rightarrow \mathrm{Fe}^{2+}+\mathrm{C}_{6} \mathrm{H}_{5} \mathrm{NO}_{2}+\mathrm{Cl}^{-} \\
\mathrm{C}_{6} \mathrm{H}_{3} \mathrm{Cl}_{2} \mathrm{NO}_{2}+2 \mathrm{e}^{-}+\mathrm{H}^{+} \rightarrow \mathrm{C}_{6} \mathrm{H}_{4} \mathrm{ClNO}_{2}+\mathrm{Cl}^{-} \\
\mathrm{C}_{6} \mathrm{H}_{4} \mathrm{ClNO}_{2}+2 \mathrm{e}^{-}+\mathrm{H}^{+} \rightarrow \mathrm{C}_{6} \mathrm{H}_{5} \mathrm{NO}_{2}+\mathrm{Cl}^{-}
\end{gathered}
$$

The LC -MS analyses carried out at a negative ion mode was used for the identification of the degradation products. Firstly, the conditions of the mass detector were optimized. The best results obtained when the drying gas was operated at $12 \mathrm{~L} \mathrm{~min}^{-1}$ flow at $340^{\circ} \mathrm{C}$. The nebulizing pressure at $60 \mathrm{psi}$, capillary voltage at $5000 \mathrm{~V}$ and the fragmentation voltage was set at $70 \mathrm{~V}$ (for PI ionization). Then, samples collected at regular time intervals were injected into the MS analysis in mode scan at different ranges, being set at two channels 1 and 2 . The products identified, as well their structure, retention time and sampling time of the process and \% relative abundance for each technology are showed in Table 2. As it can be observed, the analyzed samples during the four investigated treatments indicated the formation of several intermediates. During the photolytic process, four reaction products were identified. This means that the UV irradiation was able to break chemicals bonds: the photonic energy absorbed exceeded the bond energy as radiation at $254 \mathrm{~nm}$ which-even has more energy than the necessary to break the $\mathrm{C}-\mathrm{Cl}$ bond (dissociation energy is $330 \mathrm{~kJ} \mathrm{~mol}^{-1}$ ) and which may promote further reactivity. Those compounds were 2,5-dichloropyridine $(\mathrm{m} / \mathrm{z}=148)$, 2',3,5',6-tetrachloro[2,3'-bipyridine]-6'-carboxylic acid $(\mathrm{m} / \mathrm{z}=337)$, 3,6-dichloro- 
pyridine-2-ol $(\mathrm{m} / \mathrm{z}=163)$ and 6-chloropyridine-2-carboxylic acid $(\mathrm{m} / \mathrm{z}=157)$. These intermediates were also found during the ZVI + photolysis process. However, two more products were identified: pyridine-2-carboxylic acid $(\mathrm{m} / \mathrm{z}=122)$ and 3-chloropyridine $(\mathrm{m} / \mathrm{z}=113)$. Considering that these molecules have lower molecular weight than those obtained during the photolytic treatment, this means that the oxidations steps achieved superior levels, confirming the improvement obtained for the ZVI + photolysis process in the oxidation of the solution.

The largest number of intermediates was found for the ZVI+ EO process. As it can be processes. These byproducts are 3,6-dichloro-4,5-dihydroxypyridine-2-carboxylic acid, $\mathrm{m} / \mathrm{z}=224$ at retention time $\operatorname{tr}=11.0 \mathrm{~min}$ and 3,6-dichloro-5-hydroxypyridine-2carboxylic acid, $\mathrm{m} / \mathrm{z}=207$ at $\operatorname{tr} 9.4 \mathrm{~min}$ (set at channel\#2). At this point, it is worthy of note that during the electro-oxidation processes using BDD anodes are expected to be produced an enormous amount highly active and non-selective oxidizing species, the - OH radicals (HRs) [49, 50]. Also, it is known that one of the major mechanistic steps of ${ }^{\bullet} \mathrm{OH}$ radicals (HRs) treatment is the hydroxylation of organic compounds, especially of unsaturated bonds, through hydrogen substitution or hydroxyl addition [51-53]. However, as discussed above, not only ${ }^{\bullet} \mathrm{OH}$ radicals (HRs), but others powerful oxidants species also acts in the oxidation process. Then, smaller molecules are formed. In the case of EO process, the products were slightly different than those obtained when ZVI was applied as pre-treatment. As can be seen in the Table 2, the main products identified during the EO process were 6-chloro-3-hydroxypyridine-2-carboxylic acid $(\mathrm{m} / \mathrm{z}=174)$ and 6-chloropyridin-3-ol $(\mathrm{m} / \mathrm{z}=128)$. Conversely, for ZVI + EO process, four more products were found, 3,6-dichloro-pyridine-2-ol $(\mathrm{m} / \mathrm{z}=164)$, 6chloropyridine-2-carboxylic acid $(\mathrm{m} / \mathrm{z}=157)$, pyridine-2-carboxylic acid $(\mathrm{m} / \mathrm{z}=122)$ 
405 and 3-chloropyridine $(\mathrm{m} / \mathrm{z}=113)$. These two last products appeared to be more 406 hydrophilic than the other products, because its retention time in the C18 column was 407 lower than all other compounds, being tr $=3.6 \mathrm{~min}$ and $\operatorname{tr}=2.8 \mathrm{~min}$, respectively.

408 Table 2. Analytes identified, structure, retention time and sampling time of electrolysis 409 and \% relative abundance for each technology.

410 


\begin{tabular}{|c|c|c|c|c|c|c|}
\hline \multirow[b]{3}{*}{ Analyte } & \multirow[b]{3}{*}{ Structure } & \multirow[b]{3}{*}{$\underset{(\min )}{\operatorname{tr}}$} & \multirow[b]{3}{*}{$\mathbf{m} / \mathbf{z}$} & \multirow{3}{*}{$\begin{array}{c}\text { Photo } \\
\text { Sampling time } \\
\text { (\% rel. } \\
\text { abundance) }\end{array}$} & \multicolumn{2}{|c|}{ Technologies } \\
\hline & & & & & $\begin{array}{l}\text { ZVI + } \\
\text { Photo }\end{array}$ & EO \\
\hline & & & & & $\begin{array}{l}\text { Sampling } \\
\text { time } \\
(\% \text { rel. } \\
\text { abudance) }\end{array}$ & $\begin{array}{c}\text { Sampling } \\
\text { time } \\
\text { (\% rel. } \\
\text { abudance) }\end{array}$ \\
\hline Clopyralid & & $9.8^{* 2}$ & 191 & - & - & - \\
\hline 2,5-dichloropyridine & & 5.9 & 148 & $\begin{array}{l}240 \\
(10)\end{array}$ & $\begin{array}{l}60 \\
(30)\end{array}$ & \\
\hline $\begin{array}{l}\text { 2',3,5',6- } \\
\text { tetrachloro[2,3'- } \\
\text { bipyridine]-6'- } \\
\text { carboxylic acid }\end{array}$ & & $10.3^{* 2}$ & 337 & $\begin{array}{l}240 \\
(40)\end{array}$ & $\begin{array}{l}10 \\
(30)\end{array}$ & \\
\hline $\begin{array}{l}\text { 3,6-dichloro-pyridine- } \\
\text { 2-ol }\end{array}$ & & $4.3^{* 2}$ & 164 & $\begin{array}{l}180 \\
(10)\end{array}$ & $\begin{array}{c}10 \\
(70)\end{array}$ & $\begin{array}{r}30 \\
(70)\end{array}$ \\
\hline $\begin{array}{l}\text { 6-chloropyridine-2- } \\
\text { carboxylic acid }\end{array}$ & & $4.0^{* 2}$ & 157 & $\begin{array}{l}240 \\
(70)\end{array}$ & $\begin{array}{c}10 \\
(100)\end{array}$ & \\
\hline $\begin{array}{l}\text { pyridine-2-carboxylic } \\
\text { acid }\end{array}$ & & 3.6 & 122 & & $\begin{array}{c}10 \\
(40)\end{array}$ & \\
\hline 3-chloropyridine & & 2.8 & 113 & & $\begin{array}{r}10 \\
(40)\end{array}$ & \\
\hline $\begin{array}{l}\text { 6-chloro-3- } \\
\text { hydroxypyridine-2- } \\
\text { carboxylic acid }\end{array}$ & & $9.6^{* 2}$ & 174 & & & $\begin{array}{r}10 \\
(70)\end{array}$ \\
\hline 6-chloropyridin-3-ol & & 3.7 & 128 & & & $\begin{array}{l}60 \\
(60)\end{array}$ \\
\hline $\begin{array}{l}\text { 3,6-dichloro-4,5- } \\
\text { dihydroxypyridine-2- } \\
\text { carboxylic acid }\end{array}$ & & $11.0^{* 2}$ & 224 & & & $\begin{array}{r}10 \\
(40)\end{array}$ \\
\hline
\end{tabular}

412 Fig. 6 shows a plausive mechanism proposed for CLP degradation based on the peaks 413 observed by LC-MS. The main pathway for each process is marked by dotted coloured 414 lines. The primary pathway of clopyralid degradation by UV irradiation (marked by 415 blue points-via 1), takes place by transfer of one electron to generated radical anion 
416 followed by decarboxylation $(-\mathrm{COOH})$ and attack of the ${ }^{\bullet} \mathrm{OH}$ radical leading to the 417 formation of 3,6-dichloropyridin-2-ol $(\mathrm{m} / \mathrm{z}=164)$. Another important reaction route is 418 the generation of the dimer 2,3,3,6-tetrachloro(2,3-bypyridine)-6-carboxylic acid. This 419 formation is caused because the clopyralid loses an electron generating a radical 420 cationic species, followed by the loss of a $\mathrm{H}^{+}$to give a radical species, which reacts with 421 the radical 2,5-dichloropyridine to form the dimer. The dimers generation is related in the literature as result of the fact that the radiation at $254 \mathrm{~nm}$ has more energy than needed to break the $\mathrm{C}-\mathrm{Cl}$ bond, as it has previously commented. This rupture leads to the formation of a chlorine radical and an unpaired electron on the carbon of the organic molecule [54]. Then, the combinations lead to form more stable molecules (e.g dimers). Similar proposals were also obtained by some other authors applying photocatalysis in the CLP treatments $[29,55]$.

A similar trend in reactivity with ZVI coupled to photolysis was observed as those ebtained with only photolysis. However, in this case, more products were identified with higher abundance during the first minutes of reactions. In this way, the main transformation of CLP is proposed to have occurred via sequential reductive dechlorination reactions, forming the monochlorinated product $(\mathrm{m} / \mathrm{z}=157)$ that ultimately generated the $\mathrm{m} / \mathrm{z}=122$, which did not contain any $\mathrm{Cl}$ atom. In addition, the 6-chloropyridine-2-carboxylic acid is attacked by $\cdot \mathrm{OH}$ radical followed by its decarboxylation $(-\mathrm{COOH})$. Once it is formed, it can be reduced to lead to 3-chloropyridine.

During the EO process (pathway 3-red line), the primary reaction route, as commented above, is the hydroxylation of the CLP on unsaturated bond of the pyridine ring, 439 through attack of hydroxyl radicals generated on BDD surface. The sequential hydroxylation forms the products of $\mathrm{m} / \mathrm{z}=207$ and with less abundance the $\mathrm{m} / \mathrm{z}=224$. 
441 Then, the 3,6-dichloro-5-hydroxypyridine-2-carboxylic acid $(\mathrm{m} / \mathrm{z}=207)$ suffers 442 decarboxylation to form the $\mathrm{m} / \mathrm{z}=164$. Another reaction route that can occur is the 443 attack of hydroxyl radical on CLP, which there is the substitution of chlorine specie by 444 hydroxyl radical to form the molecule $\mathrm{m} / \mathrm{z}=174$. From this point, oxidation reaction 445 occurs by attack of hydroxyl radical and other oxidants such as persulfates to generate 446 the decarboxylated product $\mathrm{m} / \mathrm{z}=128$ ). The oxidative ring-opening reactions follow, 447 possibly to form short-chain carboxylic acids and inorganic ions.

448 The pathway marked by green dotted points is related to ZVI as pre-treatment of the 449 electro-oxidation. As seen, the main products observed at high abundance are those 450 which there is a substitution of $\mathrm{Cl}$ species by $\mathrm{OH}$, forming the product 6-chloro-3451 hydroxypyridine-2-carboxylic acid, followed by decarboxylation via attack of powerful 452 oxidants species. Besides, the products obtained via 4 (EO-red lines) were also 453 identified, meaning that both routes are probable to occur. However, it is worthy to note 454 that albeit both pathways can occur (because products of both pathways were 455 identified), the transformation based on hydroxylation of CLP (via 4) is less important 456 than that of via reaction 3. Finally, these intermediates are degraded to $\mathrm{CO}_{2}, \mathrm{H}_{2} \mathrm{O}, \mathrm{NH}_{4}{ }^{+}$ 457 as it can be postulated on the basis TOC measurement where around $80 \%$ of 458 mineralization was attained after about $240 \mathrm{~min}$ of electroxidation. Non-mineralized 459 organics can be explained in terms of the formation of iron-carboxylic acid complexes, 460 which are known to be very refractory. However, these potential intermediates were not 461 identified with the analytical techniques used in this work. 


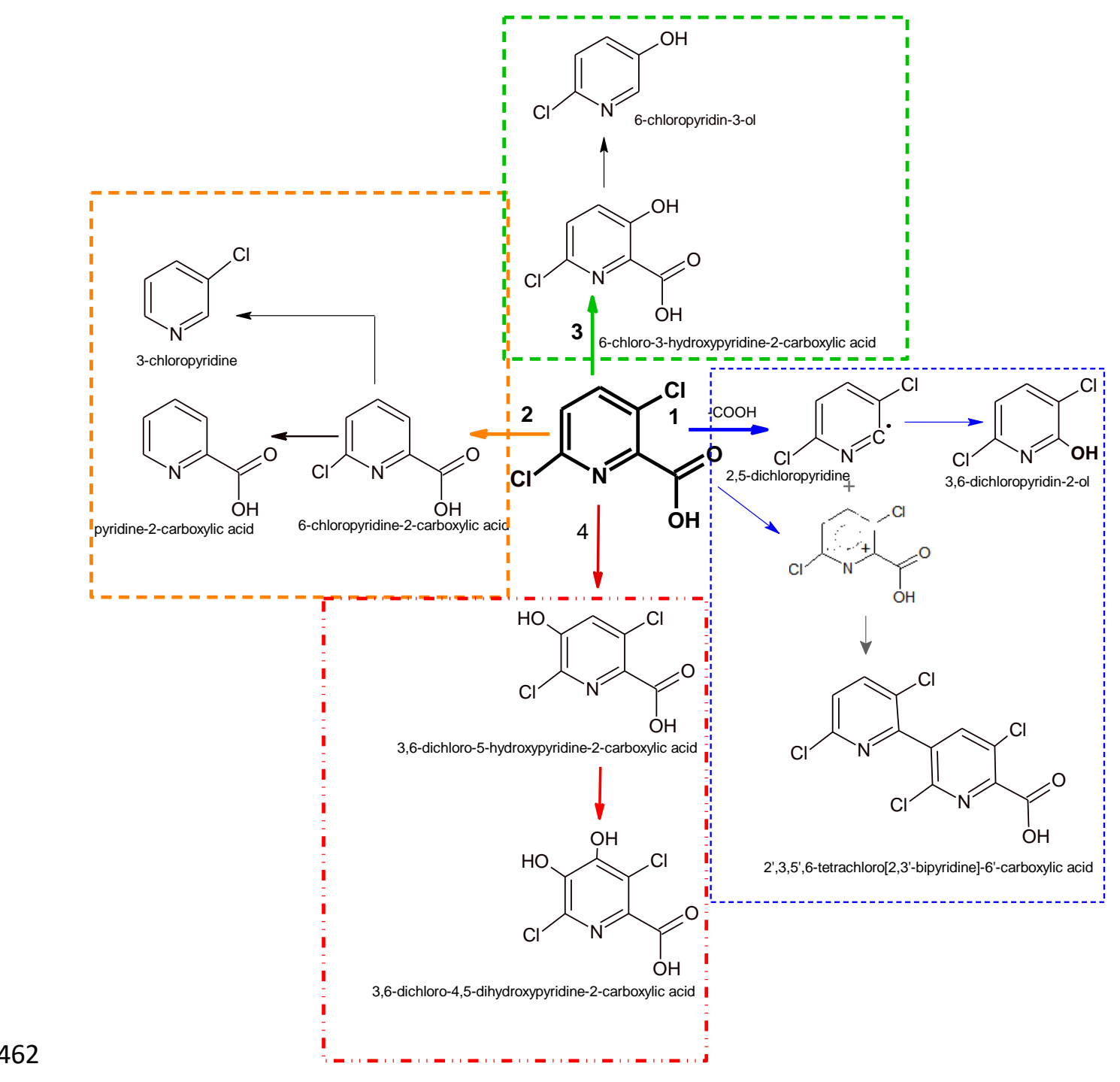

463 Figure 6: Tentative pathways for preferential clopyralid degradation by photolysis 464 (blue), ZVI + photolysis (Orange), electrooxidation (red) and ZVI + EO (green).

\section{Conclusions}

From this work, the following conclusions can be drawn:

- Single photolysis is not very efficient, and it only attains $5 \%$ of removal of the pollutant. An improvement up to $45 \%$ in the removal is obtained when ZVI was employed as pre-treatment, albeit almost $80 \%$ of organic carbon still remain in the solution after the treatment. Electro-oxidation is an excellent technology to treat clopyralid attaining $100 \%$ of removal and $78 \%$ of mineralization within 4 
$\mathrm{h}$ of reaction. ZVI as pre-treatment of EO was found to be the most efficient technique evaluated for leading more than $80 \%$ of total mineralization, slightly improving the results of the single process.

\section{Acknowledgements}

Financial support from the Spanish Agencia Estatal de Investigación through project CTM2016-76197-R (AEI/FEDER, UE) and grant FPU16/00067 is gratefully acknowledged. This work contains also first results of the Project PID2019-107271RBI00, continuation of the CTM2016-76197-R. Coordenação de Aperfeiçoamento de Pessoal de nível Superior (CAPES-Brazil) through process 88881.171154/2018-01 for the scholarship awarded to Fernanda L. Souza are gratefully acknowledged.

496

\section{References}


[1] C.A. Martínez-Huitle, M. Panizza, Electrochemical oxidation of organic pollutants for wastewater treatment, Current Opinion in Electrochemistry, 11 (2018) 62-71.

500 [2] O. Scialdone, Electrochemical oxidation of organic pollutants in water at metal oxide 501 electrodes: A simple theoretical model including direct and indirect oxidation processes at the 502 anodic surface, Electrochim. Acta, 54 (2009) 6140-6147.

503 [3] I. Sirés, E. Brillas, M.A. Oturan, M.A. Rodrigo, M. Panizza, Electrochemical advanced 504 oxidation processes: today and tomorrow. A review, Environmental Science and Pollution 505 Research, 21 (2014) 8336-8367. treatment - A review, Journal of Electroanalytical Chemistry, 754 (2015) 46-56.

[5] P. Cañizares, R. Paz, C. Sáez, M.A. Rodrigo, Costs of the electrochemical oxidation of wastewaters: A comparison with ozonation and Fenton oxidation processes, Journal of Environmental Management, 90 (2009) 410-420.

[6] I. Linares-Hernández, C. Barrera-Díaz, B. Bilyeu, P. Juárez-GarcíaRojas, E. Campos-Medina, A combined electrocoagulation-electrooxidation treatment for industrial wastewater, Journal of Hazardous Materials, 175 (2010) 688-694.

[7] M. Muñoz, J. Llanos, A. Raschitor, P. Cañizares, M.A. Rodrigo, Electrocoagulation as the Key for an Efficient Concentration and Removal of Oxyfluorfen from Liquid Wastes, Industrial \& Engineering Chemistry Research, 56 (2017) 3091-3097.

[8] J. Llanos, A. Raschitor, P. Cañizares, M.A. Rodrigo, Exploring the applicability of a combined electrodialysis/electro-oxidation cell for the degradation of 2,4-dichlorophenoxyacetic acid, Electrochim. Acta, 269 (2018) 415-421.

[9] A. Raschitor, J. Llanos, P. Cañizares, M.A. Rodrigo, Novel integrated electrodialysis/electrooxidation process for the efficient degradation of 2,4-dichlorophenoxyacetic acid, Chemosphere, 182 (2017) 85-89.

[10] M. MuñozMorales, C. Sáez, P. Cañizares, M.A. Rodrigo, A new strategy for the electrolytic removal of organics based on adsorption onto granular activated carbon, Electrochemistry Communications, 90 (2018) 47-50.

[11] M. Muñoz-Morales, C. Sáez, P. Cañizares, M.A. Rodrigo, A new electrochemically-based process for the removal of perchloroethylene from gaseous effluents, Chemical Engineering Journal, 361 (2019) 609-614.

[12] M.J. Martín de Vidales, M.P. Castro, C. Sáez, P. Cañizares, M.A. Rodrigo, Radiation-assisted electrochemical processes in semi-pilot scale for the removal of clopyralid from soil washing wastes, Separation and Purification Technology, 208 (2019) 100-109.

[13] S. Cotillas, E. Lacasa, M. Herraiz-Carboné, C. Sáez, P. Cañizares, M.A. Rodrigo, Innovative photoelectrochemical cell for the removal of $\mathrm{CHCs}$ from soil washing wastes, Separation and Purification Technology, 230 (2020) 115876.

[14] D. Montanaro, R. Lavecchia, E. Petrucci, A. Zuorro, UV-assisted electrochemical degradation of coumarin on boron-doped diamond electrodes, Chemical Engineering Journal, 323 (2017) 512-519.

[15] M.J. Martín de Vidales, C. Sáez, P. Cañizares, M.A. Rodrigo, Removal of triclosan by conductive-diamond electrolysis and sonoelectrolysis, Journal of Chemical Technology \& Biotechnology, 88 (2013) 823-828.

[16] M.J.M.d. Vidales, S. Barba, C. Sáez, P. Cañizares, M.A. Rodrigo, Coupling ultraviolet light and ultrasound irradiation with Conductive-Diamond Electrochemical Oxidation for the removal of progesterone, Electrochim. Acta, 140 (2014) 20-26.

[17] M.B. Carboneras, M.A. Rodrigo, P. Canizares, J. Villaseñor, F.J. Fernandez-Morales, Electroirradiated technologies for clopyralid removal from soil washing effluents, Separation and Purification Technology, 227 (2019) 115728.

[18] S. Cotillas, E. Lacasa, C. Sáez, P. Cañizares, M.A. Rodrigo, Electrolytic and electro-irradiated technologies for the removal of chloramphenicol in synthetic urine with diamond anodes, Water Research, 128 (2018) 383-392. 

for the in-situ generation of hydrogen peroxide, Electrochemistry Communications, 71 (2016) 552 65-68.

553 [20] J.F. Pérez, J. Llanos, C. Sáez, C. López, P. Cañizares, M.A. Rodrigo, The pressurized jet 554 aerator: A new aeration system for high-performance $\mathrm{H} 2 \mathrm{O} 2$ electrolyzers, Electrochemistry 555 Communications, 89 (2018) 19-22.

556 [21] H. Olvera-Vargas, X. Zheng, O. Garcia-Rodriguez, O. Lefebvre, Sequential "electrochemical 557 peroxidation - Electro-Fenton" process for anaerobic sludge treatment, Water Research, 154 558 (2019) 277-286.

559 [22] M. Rodríguez, M. Muñoz-Morales, J.F. Perez, C. Saez, P. Cañizares, C.E. Barrera-Díaz, M.A. 560 Rodrigo, Toward the Development of Efficient Electro-Fenton Reactors for Soil Washing Wastes through Microfluidic Cells, Industrial \& Engineering Chemistry Research, 57 (2018) 10709-10717.

[23] L. Teevs, K.D. Vorlop, U. Prüße, Model study on the aqueous-phase hydrodechlorination of clopyralid on noble metal catalysts, Catal. Commun., 14 (2011) 96-100.

[24] Z.-Y. Zhang, M. Lu, Z.-Z. Zhang, M. Xiao, M. Zhang, Dechlorination of short chain chlorinated paraffins by nanoscale zero-valent iron, Journal of Hazardous Materials, 243 (2012) 105-111.

[25] I. San Román, M.L. Alonso, L. Bartolomé, A. Galdames, E. Goiti, M. Ocejo, M. Moragues, R.M. Alonso, J.L. Vilas, Relevance study of bare and coated zero valent iron nanoparticles for lindane degradation from its by-product monitorization, Chemosphere, 93 (2013) 1324-1332. [26] Y. Han, W. Yan, Reductive Dechlorination of Trichloroethene by Zero-valent Iron Nanoparticles: Reactivity Enhancement through Sulfidation Treatment, Environmental Science \& Technology, 50 (2016) 12992-13001.

[27] C. Carvalho de Almeida, M. Muñoz-Morales, C. Sáez, P. Cañizares, C.A. Martínez-Huitle, M.A. Rodrigo, Electrolysis with diamond anodes of the effluents of a combined soil washing ZVI dechlorination process, Journal of Hazardous Materials, 369 (2019) 577-583.

[28] M.B. Ferreira, M. Muñoz-Morales, C. Sáez, P. Cañizares, C.A. Martínez-Huitle, M.A. Rodrigo, Improving biotreatability of hazardous effluents combining ZVI, electrolysis and photolysis, Science of The Total Environment, (2020) 136647.

[29] D.V. Sojic, V.B. Anderluh, D.Z. Orcic, B.F. Abramovic, Photodegradation of clopyralid in $\mathrm{TiO} 2$ suspensions: identification of intermediates and reaction pathways, J. Hazard. Mater., 168 (2009) 94-101.

[30] S. Semitsoglou-Tsiapou, M.R. Templeton, N.J.D. Graham, L. Hernández Leal, B.J. Martijn, A. Royce, J.C. Kruithof, Low pressure UV/H2O2 treatment for the degradation of the pesticides metaldehyde, clopyralid and mecoprop - Kinetics and reaction product formation, Water Research, 91 (2016) 285-294.

[31] M. Ahmadi, F. Ghanbari, Degradation of organic pollutants by photoelectro-peroxone/ZVI process: Synergistic, kinetic and feasibility studies, Journal of environmental management, 228 (2018) 32-39.

[32] E. GilPavas, S. Correa-Sánchez, Optimization of the heterogeneous electro-Fenton process assisted by scrap zero-valent iron for treating textile wastewater: Assessment of toxicity and biodegradability, Journal of Water Process Engineering, 32 (2019) 100924.

[33] F. Deng, O. Garcia-Rodriguez, H. Olvera-Vargas, S. Qiu, O. Lefebvre, J. Yang, Iron-foam as a heterogeneous catalyst in the presence of tripolyphosphate electrolyte for improving electroFenton oxidation capability, Electrochim. Acta, 272 (2018) 176-183.

[34] C. Carvalho de Almeida, M. Muñoz-Morales, C. Sáez, P. Cañizares, C.A. Martínez-Huitle, M.A. Rodrigo, Integrating ZVI-dehalogenation into an electrolytic soil-washing cell, Separation and Purification Technology, 211 (2019) 28-34.

[35] M.B. Carboneras Contreras, F. Fourcade, A. Assadi, A. Amrane, F.J. Fernandez-Morales, Electro Fenton removal of clopyralid in soil washing effluents, Chemosphere, 237 (2019) 124447. 

Royce, J.C. Kruithof, Low pressure UV/H2O2 treatment for the degradation of the pesticides metaldehyde, clopyralid and mecoprop - Kinetics and reaction product formation, Water Res, 91 (2016) 285-294.

606 [37] C. Tizaoui, K. Mezughi, R. Bickley, Heterogeneous photocatalytic removal of the herbicide 607 clopyralid and its comparison with UV/H2O2 and ozone oxidation techniques, Desalination,

608273 (2011) 197-204.

609 [38] M. Muñoz-Morales, C. Sáez, P. Cañizares, M.A. Rodrigo, Enhanced electrolytic treatment

[39] A. Raschitor, J. Llanos, M.A. Rodrigo, P. Cañizares, Is it worth using the coupled electrodialysis/electro-oxidation system for the removal of pesticides? Process modelling and role of the pollutant, Chemosphere, 246 (2020) 125781.

[40] G.O.S. Santos, K.I.B. Eguiluz, G.R. Salazar-Banda, C. Saez, M.A. Rodrigo, Photoelectrolysis of clopyralid wastes with a novel laser-prepared MMO-RuO2TiO2 anode, Chemosphere, 244 (2020) 125455.

[41] K.E. Wilzbach, D.J. Rausch, Photochemistry of nitrogen heterocycles. Dewar pyridine and its intermediacy in photoreduction and photohydration of pyridine, J. Am. Chem. Soc., 92 (1970) 2178-2179.

[42] A. Correia de Velosa, R. Nogueira, 2,4-Dichlorophenoxyacetic acid (2,4-D) degradation promoted by nanoparticulate zerovalent iron (nZVI) in aerobic suspensions, Journal of environmental management, $121 \mathrm{C}$ (2013) 72-79.

[43] C. Lee, C.R. Keenan, D.L. Sedlak, Polyoxometalate-Enhanced Oxidation of Organic Compounds by Nanoparticulate Zero-Valent Iron and Ferrous Ion in the Presence of Oxygen, Environmental Science \& Technology, 42 (2008) 4921-4926.

[44] G. Lyngsie, L. Krumina, A. Tunlid, P. Persson, Generation of hydroxyl radicals from reactions between a dimethoxyhydroquinone and iron oxide nanoparticles, Scientific Reports, 8 (2018) 10834.

[45] P. Cañizares, C. Sáez, A. Sánchez-Carretero, M.A. Rodrigo, Synthesis of novel oxidants by electrochemical technology, Journal of Applied Electrochemistry, 39 (2009) 2143.

[46] J.M. Aquino, M.A. Rodrigo, R.C. Rocha-Filho, C. Sáez, P. Cañizares, Influence of the supporting electrolyte on the electrolyses of dyes with conductive-diamond anodes, Chemical Engineering Journal, 184 (2012) 221-227.

[47] F. Souza, S. Quijorna, M.R.V. Lanza, C. Sáez, P. Cañizares, M.A. Rodrigo, Applicability of electrochemical oxidation using diamond anodes to the treatment of a sulfonylurea herbicide, Catalysis Today, 280 (2017) 192-198.

[48] M. Minella, E. Sappa, K. Hanna, F. Barsotti, V. Maurino, C. Minero, D. Vione, Considerable Fenton and photo-Fenton reactivity of passivated zero-valent iron, RSC Advances, 6 (2016) 86752-86761.

[49] B. Marselli, J. Garcia-Gomez, P.A. Michaud, M.A. Rodrigo, C. Comninellis, Electrogeneration of Hydroxyl Radicals on Boron-Doped Diamond Electrodes, Journal of The Electrochemical Society, 150 (2003) D79.

[50] I. Duo, A. Fujishima, C. Comninellis, Electron transfer kinetics on composite diamond (sp3)-graphite (sp2) electrodes, Electrochemistry Communications, 5 (2003) 695-700. [51] M.G. Antoniou, J.A. Shoemaker, A.A. de la Cruz, D.D. Dionysiou, LC/MS/MS structure elucidation of reaction intermediates formed during the $\mathrm{TiO}(2)$ photocatalysis of microcystinLR, Toxicon : official journal of the International Society on Toxinology, 51 (2008) 1103-1118. [52] L.P. Cermenati, P.; Guillard, C.; Albini, A., Probing the TiO2 Photocatalytic Mechanisms in Water Purification by Use of Quinoline,Photo-Fenton Generated $\mathrm{OH} \bullet$ Radicals and Superoxide Dismutase, J. Phys. Chem. B, 101 (1997) 2650-2658. 
[53] N. Rabaaoui, K. Saad Mel, Y. Moussaoui, M.S. Allagui, A. Bedoui, E. Elaloui, Anodic oxidation of o-nitrophenol on BDD electrode: variable effects and mechanisms of degradation, Journal of hazardous materials, 250-251 (2013) 447-453. [54] O.S. Keen, E.M. Thurman, I. Ferrer, A.D. Dotson, K.G. Linden, Dimer formation during UV photolysis of diclofenac, Chemosphere, 93 (2013) 1948-1956.

656 [55] C. Berberidou, V. Kitsiou, S. Karahanidou, D.A. Lambropoulou, A. Kouras, C.I. Kosma, T.A. Albanis, I. Poulios, Photocatalytic degradation of the herbicide clopyralid: kinetics, degradation pathways and ecotoxicity evaluation, Journal of Chemical Technology \& Biotechnology, 91

659 (2016) 2510-2518.

660 